\title{
The monitoring of rammed earth experimental walls and characterization of rammed earth samples
}

\author{
P. Faria, V. Silva \& C. Pereira \\ Nova University of Lisbon, Portugal \\ M. Rocha \\ Architect, Serpa, Portugal
}

\begin{abstract}
This article analyzes differences recorded in the construction and ageing of experimental rammed earth walls. After 10-12 years of exposure some superficial degradation was observed in some walls, pointing to the necessity of applying a compatible surface protection. The behavior of samples of the rammed earth similar to those used in the walls is also analyzed in terms of density, thermal conductivity, capillary absorption and drying. A different behavior was recorded between: different unstabilized soils, the same soil but with different grading, the same soil but stabilized with different hydraulic binders and different soils stabilized with the same binder.
\end{abstract}

\section{INTRODUCTION}

Earthen construction techniques are used since mankind learnt how to build shelters (Bruno et al. 2010). They were abandoned in Portugal in the 50's but in the last couple of decades (mainly since the 90's) regain interest and application. Fortunately the craftsmanship was not totally lost but those who used to build with earth are now elderly masons. Also since the 90's professional courses in the area have appeared.

In Southern Portugal almost every dwellings built prior to the 50's has earth-based walls. The exterior walls were made using rammed earth techniques and the interior walls with the same technique or alternatively using adobe masonry or framed earth. Portugal is a seismic area and many of these old buildings have already resisted to (weak) seismic activity.

The majority of Portuguese earth buildings are dwellings, but earthen techniques can also be found in many other types of constructions, and even in national monuments.

The problem of durability of rammed earth walls still raises questions, although there are very ancient buildings, hundreds of years old, all over the world, with satisfactory performance (Mileto et al. 2011). Problems are often about seismic action and water sensibility. Some researchers have considered that problems due to loss of strength when saturated with water, erosion due to wind and driving rain and lack of dimensional stability can be significantly reduced by stabilizing the soil with hydraulic binders.

Many new buildings have been constructed in Portugal (mainly in the Alentejo region) and across the world. In the case of new buildings, appropriate design - for instance the creation of a suitable roof covering, a basement for avoiding capillary rise from the soil and the use of compatible materials may suffice to guarantee good behavior in terms of resistance to water and moisture drying.

Degradation mainly occurs when the buildings are left without maintenance, abandoned to natural ageing. Some old buildings have been the object of rehabilitation and/or conservation efforts. These interventions are often not well designed and succeeded mainly because of the use of cement based mortars to overcome earth walls degradation (FariaRodrigues 2006, Gomes \& Faria 2011). Frequently the pathology caused by these wrong interventions is much worse than the original problem and often becomes irreversible.

Earthen constructions offer several advantages such as thermal and acoustic comfort, local employment creation, minimal impact on the environment (Morel et al. 2001, Venkatarama Reddy \& Kumar 2010), the valorization of cultural and social techniques, workmanship and human traditions.

Allinson \& Hall (2010) stated that stabilized rammed earth contributes to reduce the amplitude and fluctuation of relative humidity indoors and the frequency of high humidity periods at the wall surface. Hall \& Allinson (2008) consider stabilized rammed earth a "high thermal mass fabric". In terms of passive cooling, peak indoor temperature is reduced when an excess heat gain is absorbed by the walls and cooled overnight.

The present article intends to approach the characterization and durability of rammed earth walls from 
complementary perspectives: the comparison in terms of rammed earth construction and visual analysis of the weathering of experimental rammed earth walls, especially prepared for observation over time with natural exposition, and the characterization of rammed earth samples in terms of density, thermal conductibility, water capillary and evaporation. Furthermore, other tests can also be made on the walls and on the rammed earth samples.

The construction of the walls was included in professional school courses, involving students of level 3 in Traditional Building Techniques degree of the Professional School of Serpa (Alentejo, Portugal) (Rocha \& Faria 2005). Serpa is located at the interior of Alentejo region, Portugal, about $100 \mathrm{~km}$ to the Atlantic coast, close to the border with Spain. It is about $25 \mathrm{~km}$ from the national weather station of the city of Beja. Data collected between 1971 and 2000 indicates that the average temperature is $16.5^{\circ} \mathrm{C}$, with a minimum of $-3.2^{\circ} \mathrm{C}$ (February/March) and a maximum of $45.2^{\circ} \mathrm{C}$ (July). The monthly precipitation average is $47.6 \mathrm{~mm}$, with a daily maximum of $111.3 \mathrm{~mm}$.

Besides the above mentioned fact of allowing to perform a continuous observation of the walls degradation over time, this method allowed the students to achieve other important skills while building it.

During the construction of the walls, plans were made to store some quantity of soils for further characterization. Rammed earth samples were also made with the same soils and similar additions, with a view to trying to reproduce the rammed earth walls.

Finally, now in the near future, the aged walls were planned to be used as substrate to allow the in situ application of consolidants, of repair mortars and of rendering mortars and to allow its evaluation on rammed earth walls conservation and repair.

But the inclusion of wall's construction procedures in the student courses made things a little more difficult than expected. This did not go exactly as planned because of different pedagogical aspects that had to be prioritized. Some deficiencies were identified: not all the different soils that were used were stored for characterization; the rammed earth samples that were made did not reproduce all the walls that were built; some rammed earth samples were made with binder additions but reference samples of the same soil and compaction without addition were not made. These deficiencies will be resolved in later campaigns.

The behavior of another set of experimental walls as well as its behavior with the application of different superficial protections were analyzed by Dayre (1993) and Bui et al (2009).

Concerning rammed earth sample tests many standards exist, including test procedures (JiménezDelgado \& Cañas-Guerrero 2007, Cid et al. 2011, Gomes et al. in press). It is common to find different versions for the same test. They should be unified so that comparison of results could be facilitated.

Hall \& Djerbib (2004), Hall \& Allinson (2008, 2009a, 2009b, 2010), Allinson \& Hall (2010), Heathcote (2011) and Schroeder (2011) have analyzed rammed earth behavior in relation to water, liquid or vapor, through different methods and its relations to thermal comfort. Values of $0,56 \mathrm{~W} / \mathrm{m} . \mathrm{K}$ to $1,21 \mathrm{~W} / \mathrm{m} . \mathrm{K}$ for dry-state thermal conductivity, for stabilized rammed earth with Portland cement, with dry density from $1400 \mathrm{~kg} / \mathrm{m}^{3}$ to $2120 \mathrm{~kg} / \mathrm{m}^{3}$ are refered by these researchers.

Hall \& Allinson (2009b) consider that for highly compacted stabilized rammed earth there is no correlation between thermal conductivity and dry density and that the main parameter affecting heat transfer, when comparing materials with the same mineralogy, appears to be the degree of inter-particle contact, determined by the particle-size distribution and degree of compaction. These authors consider that the thermal conductivity increases with saturation ratio because the material acts as if it possessed thermal bridges, augmenting inter-particle contact in partially saturated soils. Differences in grading induces pore-size distribution to change and, consequently, the capillary potential.

Schroeder (2011) monitored a rammed earth wall made with coarse aggregates and straw fibers $1,5 \mathrm{~m}$ long, 1,0m high and 0,5m thick, with $12-13 \%$ optimal moisture content (OMC), for 6 months at $12^{\circ} \mathrm{C}$ temperature and $68 \% \mathrm{RH}$. The researcher states that the optimum moisture content from Proctor test was not generally the optimum level for the rapid drying of rammed earth and that an higher initial moisture content $(>10 \%)$ can accelerate the drying process. He indicates 90 days of drying as the minimal period before testing rammed earth samples.

Hall \& Djerbib (2004) observe that the total required energy input for rammed earth compaction is not a fixed value regardless of the type of soil. The researchers consider that the main factors controlling the dry density are particle-size distribution and the corresponding $\mathrm{OMC}$, and that these parameters are indexed to the strength and durability of the rammed earth. When rammed earth is produced, if insufficient quantity of water is present, the soil cannot achieve an optimal level of compaction due to greater friction between soil particles; if the water is excessive, it will occupy porous space, reducing the level of achievable compaction and increasing the porosity when the wall is dry.

\section{EXPERIMENTAL WALL SETS}

\subsection{Construction and evaluation of Horta do Chó walls}

The construction of the walls occurred during June and July 1999. In a rectangular area, 12 rammed 
earth walls were built separately at a distance of 1 meter, according to three alignments. The same orientation was used for every wall: the two major faces of the experimental walls were exposed to $\mathrm{N}$ and $\mathrm{S}$ and the two smaller faces to $\mathrm{E}$ and $\mathrm{W}$. The walls' foundations were made of concrete, with $0.40 \mathrm{~m}$ and their basement was made of stone masonry, with $0.30 \mathrm{~m}$ height. The soil was prepared with the intended optimal amount of water, and it was placed inside the formwork and compacted in successive thin layers until the top of the traditional formwork. After the formwork was filled in, it was dismounted and installed in the upper level. Each wall was completed with the two higher formworks, with final rammed earth dimensions of $0.5 \mathrm{~m}$ thick, $1.0 \mathrm{~m}$ high and $1.0 \mathrm{~m}$ long. The top of each wall was covered with two strands of tile, for protecting from rainwater.

Three types of soil were used, from different places in the municipality of Serpa (soil I, II and III). Four walls were made using each soil (walls 1, 2, 3 and 4). On walls number 4, no stabilizer was added to the soils; on walls number $3,15 \%$ volume of hydraulic lime was used as a stabilizer and on walls number $2,8 \%$ volume of cement was used. All walls were manually rammed with a traditional wooden tamper. Wall number 1 was also made with each of the three soils, without stabilizer, but has been mechanically compressed with a pneumatic hammer.

The differences in the construction of the walls allowed for a comparison of the work and the different performance of the material, using different soils and compaction methods. The walls monitoring allowed for a comparison between their performance when exposed for years to natural climatic conditions.

Regarding the implementation of the walls it was observed that when ramming was manual, soil III allowed the compression of a greater amount of material in a shorter period of time compared to other soils, independently of whether or not a soil stabilizer was introduced. Concerning the differences between the two ways of ramming unstabilized soil, it was observed that the mechanical compaction led to the introduction of more raw material in a much shorter period of time, resulting in a very compact wall in comparison to manual ramming. On the other hand, this implied "sacrificing" the formworks and required a greater pressure control of the air compressor, to avoid damaging the wood.

In terms of visual evaluation of the walls over time, it was observed, after 12 years of exposure to natural climatic conditions, that the different walls had different levels of surface degradation.

The most obvious consequence was that the walls constructed with soil stabilized with hydraulic lime revealed a lower degree of surface degradation. The walls rammed by mechanical means were in good condition. The loss of pieces of the top protection of the walls, which happened in most cases, greatly accelerated erosion not only on the surface but also in the mass of the blocks.

\subsection{Construction and evaluation of Herdade da Bemposta walls}

Like on the wall set made at Horta do Chó, the wall set built at Herdade da Bemposta consisted of 12 experimental walls. The first 6 walls were erected in the spring of 2000 and the other walls in the following spring.

The implantation was also made in a rectangular area, with one meter of distance between the walls.

The orientation given to these walls was that a $\mathrm{N} / \mathrm{S}$ axis would be coincident with the diagonal line of its rectangular base, so that one longer side and one shorter side of each wall were exposed $\mathrm{N}$ and the others South. As in the previous case, all walls have protections at the bottom and at the top. At the bottom there is a small base of concrete, with a height of $0.25 \mathrm{~m}$, to avoid direct contact with the ground. The top protection was made with a tiled capping.

Each wall consists of two overlapping rammed earth blocks, made according to the traditional method, like the above described set. Four different soils from the Serpa region were used in construction: soil A (from the western outskirts of the city walls 1 to 4), soil B (from the northeastern outskirts of the city - wall 5), soil C (site soil - walls 10 to 12) and soil D (from Serpa's urban zone - walls 7 to 9); wall 6 was never made. For the walls 8 and 12, the soils were stabilized with one part of hydraulic lime to seven parts of soil (12\% volume). The soils of walls 9 and 10 were sieved (with a mesh size of 1 $\mathrm{cm}$ ), in order to separate and remove gravel. All the walls were manually rammed, except for wall 11 which has been mechanically rammed.

The differences between the walls were intended to allow for an evaluation of the ramming of different soils (through differences in mineralogy, in grading, the addition of hydraulic lime as stabilizer and the type of ramming - manual or mechanical) as well as of the different performance of the walls when exposed to weathering.

The most remarkable observation concerned the fact that walls made with sieved soil had needed a "heavier, harder" and longer ramming; apparently the drying time of these walls was also much longer.

Regarding the evaluation of the walls over time, it was observed that, after 10-11 years of weathering, the walls without superficial protection were in very good condition, with only some superficial erosion. However, some slightly unequal levels of surface degradation should be pointed out. It was observed that the walls using stabilized soils with hydraulic lime were the ones with a lower degree of surface degradation. 


\section{RAMMED EARTH SAMPLES}

\subsection{Rammed earth sample production and curing}

Rammed earth samples were produced with soils used at the Bemposta experimental set of walls. Eight samples were made with soil A, four with soil A sieved (eliminating the coarser particles retained in $1 \mathrm{~cm} \mathrm{mesh),} \mathrm{six} \mathrm{with} \mathrm{soil} \mathrm{B,} \mathrm{two} \mathrm{with} \mathrm{soil} \mathrm{B} \mathrm{with}$ $10 \%$ volume of hydraulic lime, two with soil B with $10 \%$ volume of Portland cement, two with soil C with $10 \%$ volume of hydraulic lime, two with soil D with $10 \%$ volume of hydraulic lime and two with soil $\mathrm{D}$ with $5 \%$ volume of hydraulic lime and $5 \%$ volume of Portland cement. The samples were produced in a TESTARAM machine for BTC production. The material was placed and compressed all at once and samples resulted in an area of $14 \mathrm{~cm}$ by $12.5 \mathrm{~cm}$ height (average volume of $2425 \mathrm{~cm}^{3}$ ).

The samples were executed in 2001 and kept in a controlled laboratorial environment of $20^{\circ} \mathrm{C}$ and $65 \% \mathrm{RH}$ until 2012. All tests were held in the same controlled environment.

\subsection{Testing campaign and results}

At the age of approximately 11 years all rammed earth prismatic samples were tested for thermal conductivity $\lambda$ with an ISOMET Heat Transfer Analyzer 2104 and a $03-2.0 \mathrm{~W} / \mathrm{m} . \mathrm{K}$ probe. The samples were placed over a thermal insulation plaque and $\lambda$ was measured in two lateral faces of each sample. Average values of $\lambda$ are presented in Table 1 , as well as the average values of the density of the samples (at $65 \% \mathrm{RH})$. All values are in the range presented in chapter 1 . With a traditional $0.5 \mathrm{~m}$ thick rammed earth wall and the measured $\lambda$, $U$ values will range between 1.1-1.7 W/m $\mathrm{m}^{2} . \mathrm{K}$, always lower than the maximum for Serpa exterior walls.

Two samples of each type of material were tested for capillary water absorption, based on EN 15801 (CEN 2009). The lateral faces of the samples were watertight to enable lateral evaporation and assure unidirectional rising; the base was covered by a fine cotton tissue to enable the loss of material. The samples were regularly weight and placed with the base immerged in $5 \mathrm{~mm}$ water, over an open grid. The difference between the distinct types of material could be directly evaluated during the test by the height of the water and the lateral touch of the samples - some needed to be held with particularly care because they became very tender - and the difference between distinct samples of the same type of material was minimal. The capillary coefficient (CC), determined by the initial slope of the capillary curve, reflects the capillary velocity and the weight gain per area of contact with water induces the total amount of water that the material is able to absorb (CA) in the period of time of the test. When the test was stopped, after $6 \mathrm{~h}$ of contact with the water, the capillary absorption of some types of materials were already stabilized whilst others were still absorbing capillary water and the asymptotic value had not yet been achieved. That can be observed by the high the water (WH) attained in the samples. CC, CA and $\mathrm{WH}$ are presented in Table 1 for each type of material. Minimal CC and minimal CA induce better behavior of the rammed earth.

Table 1. Rammed earth materials and average values of thermal conductivity, density, capillary coefficient, capillary absorption after $6 \mathrm{~h}$, water high and drying index.

\begin{tabular}{|c|c|c|c|c|c|c|}
\hline Rammed & $\lambda$ & Density & Cap.Coef. & CA $6 \mathrm{~h}$ & WH & DI \\
\hline Earth & $\mathrm{W} / \mathrm{m} . \mathrm{K}$ & $\mathrm{kg} / \mathrm{m}^{3}$ & $\mathrm{~kg} / \mathrm{m}^{2} \cdot \min ^{0.5}$ & $\mathrm{~kg} / \mathrm{m}^{2}$ & $\mathrm{~mm}$ & - \\
\hline A & 0.64 & 1905 & 6.39 & 33.1 & $125^{*}$ & 0.7 \\
\hline A sieved & 1.21 & 2003 & 2.07 & 19.2 & 91 & \\
\hline B & 0.95 & 1942 & 2.30 & 27.0 & 125 & \\
\hline $\mathrm{B}+\mathrm{hl}$ & 1.05 & 1950 & 0.90 & 13.2 & 70 & \\
\hline $\mathrm{B}+\mathrm{c}$ & 0.81 & 1876 & 1.34 & 27.8 & 123 & \\
\hline $\mathrm{C}+\mathrm{hl}$ & 0.80 & 1846 & 4.34 & 23.5 & $125 * *$ & \\
\hline D+hl & 0.87 & 1874 & 2.15 & 27.8 & 125 & \\
\hline $\mathrm{D}+\mathrm{hl}+\mathrm{c}$ & 1.06 & 1990 & 1.26 & 18.6 & 96 & \\
\hline
\end{tabular}

Rammed earth: A, A sieved, B, C and D; binder stabilizers: hl $-10 \%$ volume of hydraulic lime, $\mathrm{c}-10 \%$ volume of Portland cement, hl+c $-5 \%$ volume of hydraulic lime and $5 \%$ volume of portland cement; * - in 60 min.; ** - in $150 \mathrm{~min}$

After $6 \mathrm{~h}$ of contact with water the samples began the drying test, based on RILEM (1980) and Brito et al. (2011). The samples were placed over a plane impermeable base and the evaporation was unidirectional at the same controlled environment. The weight loss was measured regularly. Because of the schedule of articles deliverance, the results of the tests were analyzed on the 3th day, but the evaporation was still going on.

The difference between the distinct types of material could be directly evaluated during the test by the changes in color of the samples and the difference between distinct samples of the same type of material was minimal. The drying index (DI) is registered in Table 1, calculated through Eq. (1) from the drying curves of each type of material:

$D I=\frac{\int_{t_{0}}^{t_{i}} f\left(W_{i}\right) \times d t}{W_{\mathrm{O}} \times t_{i}}$

where $\mathrm{f}\left(\mathrm{w}_{\mathrm{i}}\right)$ reflects the variation over time of the water content $\mathrm{w}_{\mathrm{i}}(\%), \mathrm{w}_{0}(\%)$ is the water content at the beginning of drying and $t_{i}(h)$ is the total duration of the test.

\section{DISCUSSION}

The levels of erosion observed on the experimental walls over time had an inverse evolution, that is: the strongest degradation took place in the early years, and progressed very slowly afterwards - except 
when the protection at the top of the walls began to deteriorate at Horta do Chó walls. As referred to above, the binder stabilization seems to have increased rammed earth's superficial resistance. On the other hand some unstabilized rammed earth walls also presented very good superficial appearance and integrity. In other walls, the aggregates became more visible; traditionally this means that the wall surface is ready to be rendered (FariaRodrigues 2006).

The experimental rammed earth walls are not directly representative of common walls in earthen buildings because experimental walls have two outer surfaces, whereas in a dwelling the interior atmosphere (without rain, wind and with minor temperature gradient) to which the internal face of the walls are subject is different from the external, subject to weathering (Bui et al. 2009). Anyway. a correlation between the experimental walls and current rammed earth walls can be assumed.

The observation of the experimental walls confirms the durability of the traditional unstabilized and stabilized rammed earth walls from Serpa region, exposed to natural ageing without superficial protection for 10-12 years. It also confirms the durability of traditional building walls that have undergone multiple decades of natural weathering. In similar conditions, stabilization with hydraulic lime seems not to be essential because unstabilized rammed earth also behaves properly. Stabilization with hydraulic binders may disable the natural recycling of the material at the end of its life cycle. This is not a totally positive point in sustainable development. For this reason it should be implemented only when justified. Other types of stabilization (Vegas et al. 2009) with natural and local materials more eco-friendly - were sometimes used and should be further tested.

Moreover, some care should be taken when comparing the characteristics of real walls in situ with experimental ones, and especially with small samples. The same compaction apparatus and compaction effort should be used, for test results to be meaningful and transposable. However, the level of energy input used for compaction can vary depending upon the soil type. Experimental results are directly conditioned by the dimensions, preparation and production of the sample (Hall \& Djerbib 2004, Bui \& Morel 2009, Ciancio \& Gibbings 2012). In the present case, the comparison between the compaction of experimental walls and the compaction of the cubic sample cannot be guaranteed and this can also be a problem.

Hall \& Allinson (2009b) consider that no correlation exists between $\lambda$ and density for highly compacted stabilized rammed earth. However, from the analysis of Table 1 for the analyzed rammed earth, thermal conductivity $\lambda$ is directly correlated with density. Differences obtained with the same type of soil are also to be remarked, when used directly or without the coarser particles (presenting A the best $\lambda$ and A sieved the worst). The particle-size distribution of the earth is then critical in terms of density and thermal conductivity but also in what concerns the rate at which moisture ingresses due to capillary suction (Hall \& Djerbib 2004). Through addition/subtraction of soil material (granular stabilization), the rate of capillary moisture ingress in rammed earth can be controlled. The thermal conductivity also depends on the water content.

For the analyzed samples, the $\mathrm{B}+\mathrm{hl}$ rammed earth displays the best behavior in terms of capillary absorption, being the one with slower and less water absorption during the test. On the contrary, the A rammed earth shows the worst behavior, while the A sieved presents a median behavior. It is clear that granular differentiation has in fact great importance on capillary behavior. Comparing the behavior of $\mathrm{B}+\mathrm{hl}$ rammed earth with $\mathrm{C}+\mathrm{hl}$ rammed earth it can be remarked that a similar stabilization does not control equally the capillary behavior of distinct soils. Comparing $\mathrm{B}$ with $\mathrm{B}+\mathrm{c}$ and $\mathrm{B}+\mathrm{hl}$ rammed earth, one can see that the same soil, unstabilized or stabilized with the same amount of addition but with different types of binders, behaves quite differently in terms of capillary action.

Table 1 shows that there is an inverse relation between density and capillary absorption after $6 \mathrm{~h}$ of contact with water. Drying is easier when the drying index is lower. It seems that rammed earth $\mathrm{A}$ and $\mathrm{C}+\mathrm{hl}$ present the best behavior, while $\mathrm{B}+\mathrm{hl}$ rammed earth shows more difficulty in drying. In terms of drying, the granular differentiation between rammed earth A and A sieved is also to be noted, as well as the different behavior between rammed earths with the same soil but unstabilized or stabilized with different binders. The best behavior is recorded for the unstabilized rammed earth.

Strength characteristics are not presented but tests ran with the action of water and corresponding handling of rammed earth samples has indicated that those characteristics can be differentiated according to the rammed earth moisture content. This study is still being carried out, with a view to further characterization of rammed earth walls and samples.

\section{CONCLUSION}

This paper has analyzed the differences obtained in the construction and evaluation of the ageing of experimental walls with 10-12 years of natural exposure. Good and expected behavior was observed in both unstabilized and stabilized rammed earth walls, showing that the binder stabilization of the soils is not always needed. In some cases, after more than 10 years of natural exposure, an exterior layer should be applied for protection. 
The paper also presents some characterization of rammed earth samples, similar to part of the experimental walls. The behavior of the rammed earth samples, in terms of density, thermal conductivity, capillary absorption and drying, was very distinctive according to different soils, different particle-size distribution of the same soil, the same soil with different binder stabilization and different soils with the same binder stabilization. This reveals that considerable research should continue for understanding and optimizing the characteristics of rammed earth and, therefore, for rammed earth walls to be able to meet all necessary requirements.

\section{REFERENCES}

Allinson, D. \& Hall, M. 2010. Hygrothermal analysis of a stabilised rammed earth test building in the UK. Energy and Buildings 42 (6): 845-852.

Brito, V., Gonçalves, T. \& Faria, P. 2011. Coatings applied on damp building substrates: performance and influence on moisture transport. J. Coating Technology Research 8 (4): 513-525.

Bruno, P. et al. 2010. Earth mortars use on pre-historic habitat structures in south Portugal. Case studies. J. Iberian Archaeology 13: 51-67.

Bui, Q. \& Morel, J-C. 2009. Assessing the anisotropy of rammed earth. Construction and Building Materials 23 (9): 3005-3011.

Bui, Q \& Morel, J-C., Venkatarama-Reddy, B., Ghayand, W. 2009. Durability of rammed earth walls exposed for 20 years to natural weathering. Buildings and Environment 44 (5): 912-918.

CEN. 2009. Conservation of cultural property. Test methods. Determination of water absorption by capillarity. EN 15801: 2009, Brussels.

Ciancio, D. \& Gibbings, J. 2012. Experimental investigation on the compressive strength of cored and molded cementstabilized rammed earth samples. Construction and Building Materials 28: 294-304.

Cid, I., Mazarrón, F. \& Canas I. 2011. Las normas de construcción com tierra en el mundo. Informes de la Construcción 63 (523): 159-169.

Dayre, M. 1993. Comportement de différent systèmes de protection superficielle des constructions en terre: résultats d'une campagne d'observation sur murets. In Terra 93 - 7th International Conference on the Study and Conservation of Earthen Architecture: 475-479. Silves, DGEMN.

Faria-Rodrigues, P. 2006. Renders for earth construction conservation. Houses and Towns Built with Earth: Conservation, Significance and Urban Dignity. M.Achenza, M.Correia, M.Cadinu, A. Serra (eds.), Argumentum.

Gomes, I. \& Faria, P. 2011. Repair mortars for rammed earth constructions. In XII DBMC $-12^{\text {th }}$ International Conference on Durability of Building Materials and Components, vol.2, V.P Freitas, H.Corvacho, M.Lacasse (eds.), Porto, Portugal, 689-696.

Gomes, I, Gonçalves, T. \& Faria, P. (accept). Unstabilized rammed earth: characterization of material collected from old constructions in south Portugal and comparison to normative requirements. Int. J. Archit. Heritage, Taylors \& Francis.

Hall, M. \& Allinson, D. 2008. Assessing the moisture-contentdependent parameters of stabilized earth materials using the cyclic-response admittance method. Energy and Buildings 40 (11): 2044-2051.

Hall, M. \& Allinson, D. 2009a. Analysis of the hygrothermal functional properties of stabilized rammed earth materials. Buildings and Environment 44 (9): 1935-1942.

Hall, M. \& Allinson, D. 2009b. Assessing the effects of soil grading on the moisture content-dependent thermal conductivity of stabilized rammed earth materials. Applied Thermal Engineering 29 (4): 740-747.

Hall, M. \& Allinson, D. 2010. Transient numerical and physical modeling of temperature profile evolution in stabilized rammed earth walls. Applied Thermal Engineering 30 (5): 433-441.

Hall, M. \& Djerbib, Y. 2004. Rammed earth sample production: context, recommendations and consistency. Construction and Building Materials 18 (4): 281-286.

Heathcote, K. 2011. The thermal performance of earth buildings. Informes de la Construcción 63 (523): 117-126.

Jiménez-Delgado, M.C. \& Canas-Guerrero, I. 2007. The selection of soils for unstabilized earth building: a normative review. Construction and Building Materials 21: 237-251.

Mileto, C., Vegas, F. \& López, J.M. 2011. Criterios y técnicas de intervención en tapia. La restauración de la torre Bofilla de Bétera (Valencia). Informes de la Construcción 63 (523): 81-96.

Morel, J-C. et al. 2001. Building houses with local materials: means to drastically reduce the environmental impact of construction. Building and Environment 36 (10): 11191126.

RILEM TC 25- PEM. 1980. Recommended tests to measure the deterioration of stone and to assess the efectiveness of treatment methods. Test $\mathrm{n}^{\mathrm{o}}$ II.5 - Evaporation curve. Materials \& Structures 13: 204-207.

Rocha, M. \& Faria-Rodrigues, P. 2005. Contribuição para a caracterização de paredes de terra crua. In IV SIACOT Seminário Ibero-Americano de Construção em Terra e III Seminário Arquitectura de Terra em Portugal. Monsaraz, Portugal (CD-rom).

Schroeder, H. 2011. Moisture transfer and change in strength during the construction of earthen buildings. Informes de la Construcción 63 (523): 107-116.

Vegas, F., Mileto, C. \& Cristini, V. 2009. Reinforcement of rammed earth constructions with gypsum in Aragon area, Spain. In Mediterra $2009-1^{\text {st }}$ Mediterranean Conference on Earth Architecture, 99-108.

Venkatarama-Reddy, B. \& Prasama-Kumar, P. 2010. Embodied energy in cement stabilized rammed earth walls. Energy and Buildings 42 (3): 380-385. 